\title{
Intravenous magnesium sulphate as an adjuvant in acute severe asthma refractory to conventional therapy
}

Submitted: 25-06-2014

Sir,

Beta 2 agonist \& steroid remain the main stay in the initial management of acute asthma. Aminophylline may be used in cases not responding to above treatment with certain limitations. IV Magnesium sulphate may be considerd in such cases.

A 65-year-old male was admitted to the intensive care unit with complaints of severe dyspnoea. The patient had history of bronchial asthma and systemic hypertension. The patient was conscious but restless, he was unable to lie down, showed signs of respiratory distress with accessory muscle use, he was unable to speak even a single word. Breath sounds were diminished throughout both lungs with diffuse, bilateral wheezing. The other physical examination was unremarkable. Vital signs were as follows: arterial pressure 140/80 $\mathrm{mmHg}$, heart rate $140 \mathrm{bpm} \&$ irreugularly irregular, $\mathrm{SpO}_{2} 70 \%$ in air. Temperature 100 degree F, respiratory rate $40 / \mathrm{min}$ with prolonged expiratory phase.

Promptly $\mathrm{O}_{2}$ with reservoir mask was administered. ABG showed $\mathrm{pH} 7.14$ (7.35 to 7.45 ), $\mathrm{pCO}_{2} 77 \mathrm{mmHg}$ (35 to $45 \mathrm{mmHg}$ ), $\mathrm{pO}_{2} 44.2 \mathrm{mmHg}$ (80 to $100 \mathrm{mmHg}$ ) $\mathrm{HCO}_{3}$ $28.4 \mathrm{mEq} / 1$ (22 to $26 \mathrm{mEq} / \mathrm{L})$. The patient was nebulized with salbutamol and budesonide nebulisation solution \& repeated 3 times at intervals of 20 minutes, injection hydrocortisone $200 \mathrm{mg}$ i.v. stat and $100 \mathrm{mg}$ thrice daily started. The bronchospasm persisted. In view of atrial fibrillation, intravenous aminophylline was deferred. At this point magnesium sulfate $1.25 \mathrm{gm}$ in $100 \mathrm{ml}$ normal saline was infused over 20 minutes and another $1.25 \mathrm{gm}$ was infused over next 30 minutes as the initial infusion showed improvement in his clinical symptoms. $\mathrm{SpO}_{2}$ came upto $92 \%$, his chest movement could be visible and the normal pattern of respiration was resumed, $\mathrm{FEV}_{1}$ value improved to $45 \%$. Encouraged by this result IV magnesium sulfate $2.5 \mathrm{gm}$ in $500 \mathrm{ml}$ normal saline was infused over next 24 hours along with alternate salbutamol and ipratropium nebulization every 6 hourly. There was continuous improvement in his symptoms \& $\mathrm{SpO}_{2}$ value came up and remained above $98 \%$ after two hours of magnesium sulfate infusion. After 24 hours, magnesium sulfate infusion was discontinued but alternate salbutamol and ipratropium nebulization every 6 hourly were continued. During magnesium sulfate infusion no haemodynamic changes were noticed. Biochemical parameters in the blood were within normal limits including the magnesium level $1 \mathrm{mmol} . \mathrm{L}^{-1}\left(\mathrm{~N}=0.74-1.03 \mathrm{mmol} . \mathrm{L}^{-1}\right)$. He was observed in the ICU for another day and then shifted to ward. At that time his respiratory rate was $12-16 /$ minute, $\mathrm{SpO}_{2} 98-100 \%$ in room air and $\mathrm{FEV}_{1}$ was $75 \%$ of his predicted value.

Magnesium sulphate is a safe and cheap medication with some bronchodilator effect. ${ }^{1}$ Magnesium has a predominantly intracellular action, is an important co-factor in many enzymatic reactions and is linked to cellular haemostasis. In addition, magnesium has an effect on smooth muscle cells, with hypomagnesemia causing contraction and hypermagnesemia causing relaxation of smooth muscles. There is some evidence that when magnesium is administered to asthmatic patients, it produces bronchodilatation. ${ }^{2}$ Magnesium competes with calcium for entry into smooth muscle cells, ${ }^{3}$ inhibits release of calcium from the sarcoplasmic reticulam, ${ }^{4}$ inhibit histamine release from mast cells. ${ }^{5}$ Thus I.V. Magnesium sulfate can be considered for patients with acute severe asthma who do not respond to standard therapeutic medications i.e. regular anti-asthamatics.

\section{Aswini Kumar Sahoo', S. C. Mohapatra²}

${ }^{1}$ Associate Professor, Department of Medicine, Maharajah's Institute of Medical Sciences, Nellimarla, Vizianagaram, Andhra Pradesh,

${ }^{2}$ Professor, Department of Medicine, Maharajah's Institute of Medical Sciences, Nellimarla, Vizianagaram, Andhra Pradesh,India

\section{REFERENCES}

1. Okayama H, Aikawa T, Okayama M, Sasaki H, Mue $S$ and Takishima T. Bronchodilating effect of intravenous magnesium sulfate in bronchial asthma. JAMA 1987;257:1076-1078. 
2. Noppen M, Vanmaele L, Impens $\mathrm{N}$ and Schandevyl W. Bronchodilating effect of intravenous magnesium sulphate in acute severe bronchial asthma. Chest 1990; 97:373-376.

3. Altura BM and Altura BT. Biochemistry and pathophysiology of CHF: Role for magnesium 1986; 5:134-143.

4. Dunnet $J$ and Naylen WG. Calcium efflux from cardiac sarcoplasmic reticulum: effects of calcium and magnesium. $\mathrm{J}$
Mol Cell Cardiol 1978;10:487-498.

5. Bois P. Effect of magnesium deficiency and urinary histamine in rats. Br J Exp Pathol 1963; 44:151-155.

\section{Access this article online}

Website: http://nepjol.info/index.php/AJMS 